\title{
Proteomics as the tool to search for lung disease markers in bronchoalveolar lavage
}

\author{
Isabelle Noël-Georis ${ }^{\mathrm{a}}$, A. Bernard ${ }^{\mathrm{b}}$, \\ Paul Falmagne ${ }^{\mathrm{a}}$ and Ruddy Wattiez ${ }^{\mathrm{a}, *}$ \\ ${ }^{\mathrm{a}}$ Laboratoire de Chimie Biologique, Université de \\ Mons-Hainaut, avenue du Champ de Mars 6, B-7000 \\ Mons, Belgium \\ ${ }^{\mathrm{b}}$ Unite de Toxicologie Industrielle et de Médecine du \\ Travail, Université Catholique de Louvain, Clos \\ Chapelle-aux-Champs, B-1200 Bruxelles, Belgium
}

\begin{abstract}
Most lung disorders are known to be associated to considerable modifications of surfactant composition. Numerous of these abnormalities have been exploited in the past to diagnose lung diseases, allowing proper treatment and followup. Diagnosis was then based on phospholipid content, surface tension and cytological features of the epithelial lining fluid (ELF), sampled by bronchoalveolar lavage (BAL) during fiberoscopic bronchoscopy. Today, it appears that the protein content of ELF displays a remarkably high complexity, not only due to the wide variety of the proteins it contains but also because of the great diversity of their cellular origins. The significance of the use of proteome analysis of BAL fluid for the search for new lung disease marker proteins and for their simultaneous display and analysis in patients suffering from lung disorders has been examined.
\end{abstract}

\section{History of surfactant analysis for lung diseases diagnosis}

The cellular interface between the lung and the environment is composed of a heterologous epithelium: pseudostratified in the proximal airways, cuboïdal in the distal airways and very thin in the alveoli, the latter representing more than $95 \%$ of the lung surface. Besides its primary function of providing an extensive and thin surface for gas exchanges between the blood and the air, the lung epithelium also fulfils a multitude of functions: it provides a protective barrier against in-

*Corresponding author. Tel.: +3265 37 3311; Fax: +32 6537 3320; E-mail: ruddy.wattiez@umh.ac.be. fection and injury from the environment, it contributes to the maintenance of the lung fluid balance, thereby preventing lung oedema, it is capable of normal cell turnover and regeneration after injury and, finally, it produces secretions such as mucus, host-defence proteins and surfactant [1-4].

The clinical importance of pulmonary secretions was first demonstrated in the late fifties, on infants dying from respiratory distress syndrome due to surfactant deficiency [5]. Later, synthetic surfactant therapies were shown to restore surfactant function in humans and animals [6].

Nowadays, numerous other lung diseases are associated with biochemical abnormalities of surfactant (reviewed by Griese [7]): obstructive lung diseases (asthma, bronchiolitis, chronic obstructive pulmonary disease, lung transplantation), infectious and suppurative lung diseases (cystic fibrosis (CF), chronic bronchitis, pneumonia, AIDS-related lung disease), adult respiratory distress syndrome (ARDS), pulmonary oedema, interstitial lung diseases (sarcoidosis, idiopathic pulmonary fibrosis (IPF), hypersensitivity pneumonitis, asbestosis), pulmonary alveolar proteinosis (PAP), other diseases specific to infants (neonatal respiratory distress syndrome, meconium aspiration syndrome, congenital diaphragmatic hernia, nosocomial infection in ventilated preterm neonates, chronic lung disease of prematurity, sudden infant death syndrome). Cardiopulmonary bypass and tobacco smoking also result in biochemical modifications of surfactant. Early and specific detection of these surfactant abnormalities in patients is of outstanding interest to enable accurate diagnosis, follow-up, prognosis and treatment of all lung disorders.

Since the discovery of the possibility of harvesting the surfactant by bronchoalveolar lavage (BAL), the epithelial lining fluid (ELF) has been the object of an impressive number of studies, allowing analyses of its components, their functions and their possible changes in patients suffering from lung diseases [8].

The first optimised ancestor of bronchoalveolar lavage, using a large volume of saline fluid, appeared 
at the beginning of the twentieth century and was designed to therapeutically remove lung secretions [9]. Growing interest in the study of the physiological effects of small volume bronchopulmonary lavage and in cellular immunology of the lower airways, along with technical improvements of lavage techniques, lead to the development of routine and standardized sampling, by bronchoalveolar lavage, of cells and secretions making up the thin layer of epithelial lining fluid that covers the airways and the alveoli [8].

Today, bronchoalveolar lavage is considered as a very safe procedure, with no reported lethal complication and minor side-effects compared to more invasive techniques such as transbronchial lung biopsy. Most recent publications now describe standardized washing of the right middle or lower lobe of the lung with $5 \times 20 \mathrm{ml}$ of sterile $0.9 \% \mathrm{w} / \mathrm{v}$ saline during fiberoptic bronchoscopy to obtain bronchoalveolar lavage fluid (BALF) after centrifugation [10].

Bronchoalveolar lavage is not, however, the only way of collecting ELF. Sputum induction has, for example, been proposed as a less invasive alternative to bronchoscopy for the collection of airway secretions from asthmatic subjects and patients with chronic obstructive pulmonary disease (COPD) [11]. It involves the inhalation of hypertonic saline aerosol, a stimulus known to cause bronchoconstriction in asthmatic subjects. This method, mainly restricted to the assessment of airway inflammation in asthmatic patients over 6 years old, is currently extended to the sampling of airways of subjects with cystic fibrosis [12], tuberculosis [12] and various interstitial lung diseases (ILD) [13]. Condensation of exhaled breath is, on the other hand, a newly described non-invasive way to collect material originating from the lung, including the lower respiratory tract. It is therefore fully applicable to the follow-up of airway inflammation in very young children and to the analysis of healthy subjects. Its current applications remain however limited to the analysis of hydrogen peroxide, lipid peroxidation and nitric oxide derivatives, and some inflammation parameters present in the exhaled breath condensate [14-16].

\section{BAL-based diagnosis of lung diseases}

\subsection{Phospholipid analyses}

Biochemical analyses have revealed that the main components of surfactant are phospholipids $(\sim 90 \%)$, especially dipalmitoylphosphatidylcholine $(\sim 65 \%)$ and phosphatidylglycerol, which are thought to be responsible for the decrease of alveolar surface tension. The role of the other lipid components, of which cholesterol is the most abundant $(\sim 10 \%)$ and other neutral lipids are in trace amounts only, remains to be understood [7].

Phospholipid composition and surface tension of surfactant are modified in a large number of lung diseases. An impressive number of studies have indeed demonstrated a significant decrease in the percentage of phosphatidylcholine and phosphatidylglycerol and an increase of phosphatidylinositol in total phospholipids in pulmonary surfactant of patients suffering from ARDS. Many other surfactant parameters in patients with various other lung diseases have been reviewed recently by Griese [7] and will not be discussed here.

\subsection{Cell analyses}

Much emphasis has also been given to the analysis of the cellular content of BAL, with the aim of using lung cytology as a diagnostic tool: in the normal lung, alveolar macrophages account for $80-95 \%$ of the cells in BAL samples [17]. Other cell types include lymphocytes $(<10 \%)$, neutrophils $(<5 \%)$, eosinophils $(<5 \%)$ and sometimes plasma cells $[17,18]$. Squamous epithelial cells, bronchial epithelial cells, type II pneumocytes, basophils and mast cells are also found in BAL $[19,20]$.

Morphological analyses of BAL cells reveal significant differences in a large number of lung disorders [18, 21-23]. For example, granulomatous and allergic lung diseases are characterized by an increase in the lymphocyte count and high neutrophil counts are characteristic of fibrosing processes or of occupational diseases caused by inhalation of inorganic dust. The percentage of mast cells is significantly increased in BAL of patients with asthma, sarcoidosis or fibrosis [18]. However, most cytological BAL properties are generally not specific of only one lung pathology and can therefore not be considered as disease markers by themselves. For example, a combination of multiple cytological parameters (total cell count, differential cell count, number of infected cells) was shown to provide more significant information than a single parameter for ventilatorassociated pneumonia (VAP) [19]. A computer program has also been used to distinguish between three common ILD by using a combination of several parameters originating from BAL cell analysis [24]. Some peculiar aspects of BAL cytology permits nonetheless an unambiguous diagnosis, for instance in the case of 
some infectious pneumopathies, revealed by the presence in BAL of infectious agents like pneumocystis carinii, mycobacteria, aspergillus, anguillulae [19]; non infectious pneumopathies, as BAL allows the visualisation of tumor cells, for example [19]; diffuse alveolar damage: a cellular content of BAL specific of abundant alveolar cell injury, combined with the appropriate clinical setting, allows a correct diagnosis [25].

Phenotypical analysis of the cellular content of BAL, using flow cytometry with fluorescence activated cell analysis and sorting capabilities (FACS) and with monoclonal antibodies directed against specific surface antigens, may give deeper insights into BAL cell subpopulations. For example, lymphocyte subpopulations are modified in various lung diseases, including sarcoidosis [26-28], IPF [29], idiopathic eosinophilic pneumonia [30], hypersensitivity pneumonitis [26,27], bronchiolitis obliterans organizing pneumonia (BOOP) [26]. Differential immunocytochemical staining of BAL alveolar macrophages was also described in IPF [31,32].

Finally, functional studies like spontaneous or induced proliferation assays, chemotaxic and cytotoxicity testings can be performed on BAL cells to give a more accurate information about the immunologic status of the diseased lung [17].

\subsection{Nucleic acid analyses}

BAL nucleic acids-based diagnosis encountered recently huge progresses thanks to the development of the polymerase chain reaction and its derivatives. Its most important applications today include the detection in BALF of pathogens via nested PCR $[33,34]$ and dosage of cytokins via RT-PCR $[35,36]$.

\subsection{Protein analyses}

Last, but not least, soluble proteins account for 20$30 \%$ of surfactant weight and are, to our point of view, the most promising elements of ELF leading to accurate diagnosis of lung disorders since BAL fluid samples contain a large number of different proteins: to date, more than 100 different proteins have been identified using 2-DE gel electrophoresis of BALF samples $[37,38]$. Moreover, thanks to an outstanding number of sources of BALF proteins, analysis of even a single protein in BALF will enable the integrated assessment of multiple lung parameters at a time. As a mere example, BALF Interleukin-10 has four possible origins: production by pulmonary T cells [39], alveolar macrophages [40], bronchial epithelial cells [41] and diffusion from serum across the air-blood barrier.

The wide variety of the proteins found in BALF, together with the multitude of measurements it makes possible in healthy and diseased subjects, are depicted in the next chapter.

\section{BAL proteins-based diagnosis of lung diseases}

\subsection{Protein markers originating from serum}

The major proteins in BALF are albumin (about 50\% of its total protein content), transferrin (about 5.6\%), alpha1-antitrypsin (about 3.5\%) and the immunoglobulins A and $\mathrm{G}$ (together about 30\%) [42]. All of these major proteins are identical to serum proteins and may originate from it by simple diffusion across the intact blood-air barrier. Indeed, the concentration of most serum-like proteins in BAL parallels their serum distribution in healthy subjects [42]. However, the molecular weight of serum-like proteins found in BALF range up to $160 \mathrm{kDa}$, indicating a possible size exclusion of higher molecular weight proteins [42]. The higher levels of IgG and IgA in BAL than in serum are probably a result of the secretion of these two immunoglobulins by lung tissue [42]. Together with transferrin, IgA and IgG may serve as protecting agents against bacterial and viral infections [43]. The occasional detection of alpha2-macroglobulin in BAL can be explained by its secretion by alveolar macrophages [44]. The presence of alpha1-antitrypsin probably accounts for the prevention of protease-dependent lung damage due to protease release from inflammatory cells [45]. Other minor BAL proteins that are identical to serum antigens include $\operatorname{IgM}, \operatorname{IgD}$, IgE, beta1-lipoprotein, plasminogen, complement components $\mathrm{C} 3$ and $\mathrm{C} 4$, ceruloplasmin, haptoglobin, hemopexin, prealbumin, Gcglobulin, alpha2-HS-glycoprotein, alpha1-acid glycoprotein and beta2-glycoprotein 1 [42]. It is not excluded that these serum-like proteins may also originate from blood contamination during the lavage procedure, thereby questioning the accuracy of concentration estimation of serum-like proteins in BAL.

Most interstitial lung diseases are characterized by a massive and significant rise of serum-like proteins in BALF, indicating a probable increase in the permeability of the air-blood barrier. Examples of such marker proteins are numerous and include IgG, IgA, albumin and alpha1 protease inhibitor in sarcoidosis [46,47], alpha1 antitrypsin, alpha2 macroglobulin and albumin in 
pneumonia [48], IgM, alpha2 macroglubulin and albumin in ARDS [49]. The most significant differences in serum-like proteins in BALF of patients with various lung disorders are summarized in Table 1.

In conclusion, measuring the BALF levels of serumspecific proteins could well serve as an indicator of the integrity of the air-blood barrier, provided the synthesis of these proteins is unchanged in serum and that the airblood barrier is the unique source of these serum-like antigens in BALF, which is not always the case.

\subsection{Lung-specific protein markers}

Proteins specifically produced by lung epithelial cells include four surfactant-associated proteins (SP-A, $\mathrm{B}, \mathrm{C}$ and D), the Clara cell protein (CC-16) and mucinassociated antigens (reviewed in [7,50]). The most abundant protein (3-4\% of total surfactant weight), SPA, is secreted by type II, Clara and bronchial cells. SP$\mathrm{B}$ and SP-D are produced by type II and Clara cells, and SP-C is exclusively synthesised by type II cells in the mature lung. Both SP-A and SP-B are involved in tubular myelin formation. SP-A and SP-D are involved in host defence mechanisms whereas the main function of SP-C is biophysical. CC16, which is exclusively produced by Clara cells, might be crucial for immunosuppression and inflammation down regulation [51]. Mucin KL-6 is expressed in alveolar type II and bronchiolar cells as well as on other somatic cells outside the lung. Tightly associated with cellular membranes, KL-6 is thought to be involved in lung fibrogenic processes, glycocalyx formation and host defence. Mucins 17-Q2 and 17-B1 are secreted by mucous cells in the tracheobronchial lumen, where they participate in the formation of the mucous gel and in host defence mechanisms.

Growing interest is given today to these lung-specific proteins with the expectation that their differential expression and/or post-translational modification might be an additional and useful parameter in diagnosing lung diseases. ELISA's (enzyme-linked immunosorbent assay) specific for each of these proteins have therefore been developed, enabling the determination of their absolute amount in BALF of patients with various lung disorders and healthy controls [52-57]. Differences in the amounts of lung-specific proteins in BALF may result from a wide variety of phenomena. Reduction of BALF SP's may be caused by reduction in the amount of secreting cells, or by decreased synthesis and/or release by these cells. Likewise, increase of BALF SP's may result from increase of the synthesis and/or release by secreting cells or by impaired clearance by alveolar macrophages, mucociliary transport, degradation, and absorption into the bloodstream. For instance, increased synthesis and/or release are the most plausible mechanisms explaining BALF SP-A increase in patients with sarcoidosis and HP [58]. BALF SP-A increase in pulmonary alveolar proteinosis is also due to impaired removal/degradation of surfactant [52]. Both SP-A and SP-D are significantly decreased in BALF of patients with idiopathic pulmonary fibrosis (IPF), due to decreased synthesis and/or release by lung epithelial cells [59]. Tobacco smoke was shown to significantly reduce the population of Clara cells, thereby reducing the amount of BALF CC-16 [55]. Increase in BALF KL-6 levels in various ILD's is explained by enhanced release of the mucin, due to inflammation-linked cytotoxicity [60]. All known significant differences in lung-specific proteins in BALF of patients with various lung disorders have been reviewed and are summarized in Table 1.

Some of the lung-specific proteins described above are also found in serum, as a result of their spontaneous leakage across the air-blood barrier, and thereby provide another mean of assessing the integrity of the barrier, less invasively than by measuring the levels of these proteins in BALF (reviewed in $[50,61]$ ). SPA, SP-B, SP-D, CC-16 and mucin-associated antigens are immunodetected in serum by ELISA's and their respective amounts are modified according to specific lung disorders. Serum SP-A significantly increases in patients with IPF, asbestosis and PAP. Cardiac lung oedema and ARDS are accompanied by a significant increase in SP-A and SP-B in serum. SP-D is significantly higher in serum of patients with fibrosis, PAP, tuberculosis and sarcoidosis. Serum CC-16 is higher in patients with chronic bronchitis, sarcoidosis and pulmonary fibrosis. Mucin KL-6 is elevated in serum of patients with active sarcoidosis and interstitial lung disorders (HP, IPF, COPD). Mucins 17-B1 and 17-Q2 increase in serum from patients with cystic fibrosis and ARDS, respectively.

In conclusion, the analysis of lung-specific proteins in BALF enables the evaluation of multiple lung parameters, including the number and integrity of secreting cells, their ability to synthesise and release proteins, the efficiency of the clearance systems. When performed in serum, the analysis of lung-specific proteins also enables the assessment of the air-blood barrier integrity in a less invasive fashion than by their measurement in BALF. 
Table 1

Protein modifications in BAL fluid of healthy subjects and patients with lung disorders. The first group of proteins are lung-specific proteins, the second correspond to serum-like antigens, the third group comprises proteins secreted by inflammatory proteins (ECP: Eosinophilic Cationic Protein; MCP: Monocyte Chemoattractant Protein) and the fourth group of proteins perform various functions and have been identified by proteome analysis (IgBF: Immunoglobulin Binding Factor; Uq-like: Ubiquitin-like protein; FABP: Fatty Acid Binding Protein). Up- and downarrows indicate proteins that are over- or under- represented in comparison to healthy non-smokers

\begin{tabular}{|c|c|c|c|c|c|c|c|c|c|}
\hline & $\begin{array}{l}\text { Tobacco } \\
\text { smoke }\end{array}$ & Asthma & $\mathrm{CF}$ & Pneumonia & ARDS & Sarcoidosis & IPF & Tuberculosis & PAP \\
\hline SP-A & $\begin{array}{l}\uparrow, \downarrow,= \\
\text { reviewed } \\
\text { by }[7,50]\end{array}$ & $\begin{array}{l}\downarrow \text { reviewed } \\
\text { by }[7,50]\end{array}$ & $\begin{array}{l}\uparrow,= \\
\text { reviewed } \\
\text { by }[7,50]\end{array}$ & $\begin{array}{l}\downarrow,= \\
\text { reviewed } \\
\text { by }[7,50]\end{array}$ & $\begin{array}{l}\downarrow \text { reviewed } \\
\text { by }[7,50]\end{array}$ & $\begin{array}{l}\uparrow,= \\
\text { reviewed } \\
\text { by [7] }\end{array}$ & $\begin{array}{l}\downarrow,= \\
\text { reviewed } \\
\text { by [7] }\end{array}$ & $\begin{array}{l}\uparrow \text { reviewed } \\
\text { by [50] }\end{array}$ & $\begin{array}{l}\uparrow \text { reviewed } \\
\text { by }[7,50]\end{array}$ \\
\hline SP-B & & & $\begin{array}{l}=\text { reviewed } \\
\text { by [50] }\end{array}$ & $\begin{array}{l}=\text { reviewed } \\
\text { by }[7,50]\end{array}$ & $\begin{array}{l}=\text { reviewed } \\
\text { by }[50]\end{array}$ & & & & \\
\hline SP-C & & & & & & & & & $\begin{array}{l}\uparrow \text { reviewed } \\
\text { by [7] }\end{array}$ \\
\hline SP-D & $\begin{array}{l}\downarrow \text { reviewed } \\
\text { by }[7,50]\end{array}$ & & & & & $\begin{array}{l}=\text { reviewed } \\
\text { by }[7,50]\end{array}$ & $\begin{array}{l}=\text { reviewed } \\
\text { by }[7,50]\end{array}$ & & $\begin{array}{l}\uparrow \text { reviewed } \\
\text { by }[7,50]\end{array}$ \\
\hline CC-16 & $\begin{array}{l}\downarrow \text { reviewed } \\
\text { by [50] }\end{array}$ & $\begin{array}{l}\downarrow \text { reviewed } \\
\text { by [50] }\end{array}$ & & & $\begin{array}{l}\uparrow \text { reviewed } \\
\text { by }[50]\end{array}$ & $\begin{array}{l}=\text { reviewed } \\
\text { by }[50]\end{array}$ & $\begin{array}{l}\downarrow \text { reviewed } \\
\text { by }[50]\end{array}$ & & \\
\hline KL-6 & & & & & & $\begin{array}{l}\uparrow \text { reviewed } \\
\text { by }[50]\end{array}$ & $\begin{array}{l}\uparrow \text { reviewed } \\
\text { by }[50]\end{array}$ & & $\uparrow[56]$ \\
\hline Albumin & $\uparrow[86]$ & $\uparrow[87]$ & & & $\uparrow[49]$ & $\uparrow[46,47,90]$ & & $\uparrow[88]$ & \\
\hline IgA & $\downarrow[89]$ & & & & & $\uparrow[46,47,90]$ & & & \\
\hline IgG & $\uparrow[42]$ & & & & & $\uparrow[46,47,90]$ & & & \\
\hline $\operatorname{IgM}$ & & & & & $\uparrow[49]$ & & & & \\
\hline $\begin{array}{l}\alpha 1 \text {-proteinase } \\
\text { inhibitor }\end{array}$ & & & & & & $\uparrow[46,47]$ & & & \\
\hline$\alpha 1$-antitrypsin & & & & $\uparrow[48]$ & & $\uparrow[88,91]$ & $\uparrow[91]$ & $\uparrow[88]$ & \\
\hline$\alpha 2$-macroglobulin & $\uparrow[92]$ & $\uparrow[87]$ & & $\uparrow[48]$ & $\uparrow[49]$ & $\uparrow[88]$ & & $\uparrow[88]$ & \\
\hline Transferrin & & & & & & $\uparrow[91]$ & & & \\
\hline Transthyretin & & & & & & $\uparrow[91]$ & & & \\
\hline IL-18 & & & & & & $\uparrow[93]$ & & & \\
\hline IL-16 & $\uparrow[94]$ & & & & & & & & \\
\hline IL-12 & & & & & & $\uparrow[95]$ & & & \\
\hline IL-10 & & $\downarrow[96]$ & $\downarrow[97]$ & & $\downarrow[40]$ & & & & \\
\hline TNFalpha & & & $\uparrow[97]$ & $\uparrow[98]$ & $\uparrow[40]$ & $\uparrow[64]$ & & $\uparrow[67]$ & \\
\hline GM-CSF & & & & & & $\uparrow[99]$ & & & $\uparrow[100]$ \\
\hline G-CSF & & & & $\uparrow[98]$ & & & $\uparrow[65]$ & & \\
\hline IL-8 & & $\uparrow[101]$ & $\uparrow[97]$ & $\uparrow[66]$ & & $\uparrow[102]$ & $\uparrow[102]$ & & \\
\hline IL-6 & & & $\uparrow[97]$ & $\uparrow[98]$ & & & & $\uparrow[67]$ & \\
\hline IL-1beta & & & $\uparrow[97]$ & & & & & $\uparrow[67]$ & \\
\hline Myeloperoxidase & & & & $\uparrow[66]$ & & & & & \\
\hline MCP-1 & & $\uparrow[68]$ & & & & $\uparrow[102,103]$ & $\uparrow[102]$ & & \\
\hline MCP-4 & & $\uparrow[69]$ & & & & & & & \\
\hline Eotaxin & & $\uparrow[70]$ & & & & & & & \\
\hline ECP & & $\uparrow[104]$ & & & & & & & \\
\hline Tryptase & $\uparrow[105]$ & $\uparrow[72]$ & & & & & & & \\
\hline Histamine & $\uparrow[105]$ & $\uparrow[72,104]$ & & & & & & & \\
\hline Ceruloplasmin & $\downarrow[89]$ & & & & & & & & \\
\hline Pro-apolipo. A1 & $\downarrow[89]$ & & & & & & & & \\
\hline Lipocalin-1 & $\uparrow[38]$ & & & & & & & & \\
\hline $\operatorname{IgBF}$ & $\uparrow[38]$ & & & & & & & & \\
\hline Cystatin S & $\uparrow[38]$ & & & & & & & & \\
\hline Cathepsin D & & & & & & & $\uparrow[91]$ & & \\
\hline Saposin D & & & & & & & $\uparrow[91]$ & & \\
\hline Uq-like & & & & & & & $\uparrow[91]$ & & \\
\hline FABP & & & & & & & $\uparrow[91]$ & & \\
\hline Calvasculin & & & & & & & $\uparrow[91]$ & & \\
\hline $\begin{array}{l}\text { Intestinal trefoil } \\
\text { factor }\end{array}$ & & & & & & & $\uparrow[91]$ & & \\
\hline Calgranulin & & & & & & & $\uparrow[91]$ & & \\
\hline Tropomyosin & & & & & & & $\uparrow[91]$ & & \\
\hline
\end{tabular}


Table 1 (cont.)

\begin{tabular}{|c|c|c|c|c|c|c|c|}
\hline & $\begin{array}{l}\text { Tobacco } \\
\text { smoke }\end{array}$ & Asthma & $\mathrm{CF}$ & Pneumonia ARDS & Sarcoidosis & IPF & Tuberculosis PAP \\
\hline Calreticulin & & & & & & $\uparrow[91]$ & \\
\hline Calcyclin & & & & & & $\uparrow[91]$ & \\
\hline
\end{tabular}

\subsection{Protein markers produced by lung inflammatory cells}

Increasing interest in the understanding of the mechanisms involved in the establishment of inflammation during lung diseases in the last decades lead to such a flood of informations about the cytokinic factors secreted by inflammatory cells in the lung tissue it would be presumptuous to try to review them exhaustively. Some recent examples for the most studied diseases are cited hereafter and are outlined in Table 1. During ARDS, pro-inflammatory TNFalpha increases in BAL whereas anti-inflammatory cytokine IL10 decreases [40]. Consistent with this, increased IL10 in the BALF of ARDS patients is correlated with patient survival [62]. On the contrary, persistent elevation of inflammatory cytokines in BALF predicts a poor outcome in ARDS [63]. During sarcoidosis, TNFalpha levels were shown to increase in BAL, with concomitant increase of its inhibitor, TNFalpha receptor [64]. Granulocyte-Colony stimulating factor (G-CSF) is detected in BALF of IPF patients while it remains under the detection limits in BALF of healthy volunteers [65]. In BALF of patients with pneumonia, IL8 , the major polymorphonuclear neutrophils chemoattractant cytokine, is significantly increased, as well as myeloperoxidase, which is released by neutrophils degranulation [66]. In BALF of patients with tuberculosis, TNFalpha, IL-1beta and IL-6 are significantly increased [67]. Chemotaxins MCP1, MCP4 and Eotaxin are increased in BAL fluid of asthma patients [6870]. Neutrophils are also responsible for the synthesis of elastase and two other matrix metalloproteinases: collagenase and gelatinase. The enzymatic activity of these three proteinases is increased in ELF of emphysematous patients, where it is responsible for the progressive destruction of extracellular matrix [71]. Tryptase and histamine in bronchoalveolar lavage fluid (BALF) are used as indicators of pulmonary mast cell activation [72].

In conclusion, inflammatory cells present in the lung are diverse and secrete a wide variety of proteins in ELF. Assaying these proteins in BALF by ELISA's and/or enzymatic activity tests will give insights on the current stage of any lung disease, in correlation with the immunological status of the patient. Furthermore, measuring cytokines in BALF has also proven to give insights into the comprehension of the mechanisms involved in lung pathogeneses.

\subsection{Other protein markers}

Oxidative burst plays a crucial role in the genesis of inflammatory lung diseases: reactive oxygen metabolites are released by alveolar macrophages, neutrophils and eosinophils during inflammation. BALF Manganese SuperOxide Dismutase is highly expressed by pneumocytes II and alveolar macrophages in the granulomas of pulmonary sarcoidosis and extrinsic allergic alveolitis in response to pro-inflammatory cytokines [73]. Metal-catalysed oxidation of BALF proteins, revealed by their carbonyl content, has been observed in patients with ILD, ARDS and chronic bronchitis [74-77].

BALF alkaline phosphatase is produced by pneumocytes II and is a marker of tissue damage in IPF and BOOP [78]. sFas and sFasL levels, revealing apoptosis, have been measured in BALF of patients with IPF, interstitial pneumonia associated with collagen vascular diseases (CVD-IP), BOOP, and ARDS using ELISA [79, 80]. sFasL is increased in all four disorders compared to control subjects, especially elevated in ARDS patients who died [79]. Moreover, an elevation of the BALF sFas level in BOOP patients, abrogating sFasL cytotoxicity, is associated with better prognosis of BOOP, compared to IPF or CVD-IP [80]. sFas antigen was also analysed by immunocytochemistry in BAL cells: expression in alveolar macrophages was higher in patients with sarcoidosis, lung cancer and fibrosis than in healthy controls [81].

Despite the wide variety of available tumour markers in bronchoalveolar lavage (neuropeptides [82], carbohydrate antigen, carcinoembryonic antigen, neuron specific enolase, squamous cell carcinoma antigen, tissue polypeptide antigen, tissue polypeptide specific antigen, cytokeratin fragment 19, ferritin, antigens Cag25 and CanAg50 [83-85]), none could be defined as diagnostic by itself, most studies advising the use of a combination of several of them to unambiguously diagnose lung carcinomas.

In summary, the protein content of BALF displays a huge complexity, due to the enormous diversity of 
proteins it contains and the variety of origins of each protein considered. Whereas measuring changes in the levels of one particular protein species gives insights into some particular mechanism affected in a defined lung disease, it is, in general, insufficient to establish a unambiguous diagnosis of one particular disease, allowing proper treatment and follow-up: the combinational analysis of several protein markers is most often recommended. In this context, the use of proteomics, as a means to simultaneously display and analyse large amounts of protein markers and/or as a search tool for new lung disease markers in BALF, is discussed in the last part of this review.

\section{Simultaneous display and search for new lung disease markers by BAL proteomic analysis}

From the abundant studies describing known BAL proteins as potential lung disease markers, it appears obvious that there could also exist unidentified proteins, present amongst the wide variety of proteins of BAL, which concentration varies specifically with one or another lung disorder, and that could therefore become helpful markers for accurately diagnosing lung diseases. The search for such protein markers in the BAL proteome, i.e. all the proteins present in BAL, was therefore initiated and encountered important developments owing to the improvement of all the techniques involved in proteomic analysis. On the other hand, proteome-wide expression analyses also enables simultaneous examination of proteins levels which concentration can be modified as a consequence of changing physiological conditions or diseases. $\mathrm{Nu}$ merous examples of the use of proteomics for the study of human diseases exist, including the development new drugs (expression proteomics [106]), the diagnosis of neurological disorders (Alzheimer's disease [107]), the identification of tumor associated protein markers (bladder, kidney, breast, lung, ovarian, prostate cancer, leukaemia, neuroblastoma (reviewed in [108]), the search for proteins associated with dilated cardiomyopathy (reviewed in [109]) and, in the context of infectious diseases, the hunt for new diagnostic markers, candidate antigens for vaccines [110] and determinants of virulence [111].

The current tool for displaying a proteome is twodimensional gel electrophoresis (2-DE), that has proven to be particularly suited to provide specific diagnostic information from various body fluids such as seminal fluid, aqueous humor, blood, cerebrospinal fluid, urine, and BALF [112]. In 2-DE, proteins are separated according to their isoelectric point in the first dimension and to their molecular weight in the second. Once stained, the resulting two-dimensional protein maps can be compared, the objective being, in differentialdisplay proteomics [113], to search for and identify proteins that are up- or downregulated in a disease-specific manner for further use as diagnostic markers.

The first 2-DE map of lung lavage effluents was published more than 20 years ago [114]. It provided a comparison of BALF 2-DE of patients with PAP with normal subjects. The premises of differentialdisplay proteomics of BALF were set, along with the search for lung-specific disease markers. BALF protein identifications were originally performed with groupspecific staining, comparisons with purified references standards and pattern matching with 2-DE maps of serum samples. It resulted in the identification of 23 serum-like proteins [42]. At the beginning of the nineties, Lenz and coworkers used the improved method for Isoelectric Focusing developed by Görg and coworkers (Immobilized PH Gradient, IPG [115]) for the first-dimensional separation of BAL fluid proteins and obtained satisfactory and well reproducible separation [90,116]. They identified SP-A among the 400 spots of a BALF 2-DE gel ( $\mathrm{pH} 4-7$ ) by comparison with 2-DE pattern of purified SP-A [90] and showed that BALF SP-A, along with IgG, IgA and 15 other spots of unknown identity, were modified in IPF, sarcoidosis and/or asbestosis [90]. These observed modified SP-A levels in 2-DE gels of BALF of patients with IPF [90] are in agreement with our 2-DE results [91] and also with previous reports showing that ELISA-detected SPA was significantly decreased in IPF [117]. Working with IPG strips ranging from $\mathrm{pH} 3$ to 10 , Lindahl and coworkers could detect approximately 1000 spots [118] and rose to 29 the number of proteins identified in BALF, which corresponds to 35-40\% of all spots [89]. The newly identified proteins included isoforms of lipocortin-1, CC-16, lysozyme and lactoferrin, which may all turn out to be useful markers of lung inflammation [89], especially anti-inflammatory lipocortin1 and $\mathrm{CC}-16$, because their isoform distribution was shown to be altered in BALF from smokers [119]. Lindahl et al. also pinpointed other significant differences in BAL fluid 2-DE pattern between smokers and nonsmokers [120] including IgA, ceruloplasmin and proapolipoprotein A-1 [89]. In 1999, the same authors described the identification, by $\mathrm{N}$-terminal sequencing, of several new and clinically interesting proteins [38]. Lipocalin-1 may function as a scavenger against toxic 
and proinflammatory lipids [121] and has cysteine proteinase inhibitor function [122]. Bronchial secretions from patients with $\mathrm{CF}$ were shown to contain higher levels of lipocalin-1, due to an up-regulated expression of the LCN1 gene [121] and BALF from smokers contain more lipocalin-1 than BALF from nonsmokers [38]. Cystatin $\mathrm{S}$ is thought to protect against cystein proteinases inhibitors originating from invading microorganisms or lysosomes. The two identified forms of cystatin $\mathrm{S}$, probably differing from each other by their phosphorylation status, were decreased in BALF from smokers versus nonsmokers [38]. Immunoglobulin binding factor (IgBF), which is abundant in human seminal plasma but has also been found in BALF, may act as a modulator of local immune reponses, and is higher in smokers than in nonsmokers [38,123].

Wishing to characterize the nature of protein BALF components, we undertook an exhaustive identification of all proteins present in human BAL fluid [37]. Our strategy to construct a protein map that contains the widest range of proteins was based on the analysis of individual and pooled BAL fluid samples from patients suffering from various lung disorders. The use of a wide nonlinear gradient IPG to separate proteins with pI between 3 and 10 in the first dimension and of a flat, ultra-thin, horizontal gradient polyacrylamide gel to separate proteins with molecular masses from 5 to $400 \mathrm{kDa}$ in the second dimension strongly increased the amount of information obtainable from BALF 2DE gels. Our present BALF 2-DE map comprises over 1200 silver stained spots $([37,91]$; our unpublished results). Over 900 protein spots were identified by matching with the human plasma reference $2-\mathrm{DE}$ map or with other miscellaneous cell line maps available from SWISS-2D PAGE (macrophage-like, epidermal keratinocyte, liver), by $\mathrm{N}$-terminal or internal amino acid microsequencing and mass spectrometry (peptide mass fingerprinting) ([37,91]; our unpublished results). A dynamic 2-DE database for human BALF was made available on the Worldwide Web in 2000 (http://w3.umh.ac.be/ / biochim/proteomic.htm [91]).

The construction of such BAL 2-DE database would obviously not be of great use if it were not to be associated with comparative proteomic analysis of patients with lung disorders. In 2000, a comparison of BALF 2-DE gels of patients with ILD (hypersensitivity pneumonitis, idiopathic pulmonary fibrosis and sarcoidosis) was published [91] and we could identify, with the assistance of our BAL database, a minimum of 50 protein spots displaying modified expression levels for each lung disease compared to healthy subjects. As an example, a comparison of 2-DE of BALF from IPF, sarcoidosis patients and healthy controls is shown in Fig. 1. The study was done on 15 healthy subjects, 10 patients with IPF and 15 with sarcoidosis, all being nonsmokers. Dramatic increases of some plasma proteins (transferrin, transthyretin, alpha-1 antitrypsin and immunoglobulins) are observed in patients with sarcoidosis. This result is a confirmation of previous observations reporting increases in serum proteins in BALF of sarcoidosis patients [46,47]. The most likely mechanism for this elevation is an increased protein leakage from the bloodstream to the lung tissues caused by inflammatory damage to the alveolar-capillary barrier. Concentration of SP-A, the most abundant pulmonary surfactant protein, is down regulated in BALF of patients with IPF, which has been observed previously in 2-DE gel experiments and ELISA's [90,117], and is probably the consequence of an alteration of the synthesis and/or release of this lung-specific protein, caused by alveolar type II cells damage. High levels of three forms of calgranulin A (spots 201, 202 and 206) are also observed in BALF of IPF patients compared to healthy ones as well as an increase in number and intensity of small and acidic proteins. These include calcium binding proteins (calcyclin, spot 212 and calvasculin, spot 216), lipid binding proteins (epidermal fatty acid-binding protein, spot 174 and adipocyte fatty acid-binding protein, spot 183), enzymes (cathepsin D, spots 108, 174 and 207; saposin D chain, spot 210) and miscellaneous proteins (intestinal trefoil factor, spot 179 and ubiquitin-like protein, spot 212). Most of these proteins have been involved in a variety of processes related to cell proliferation, but their exact role in IPF pathogenesis remains to be discovered. The presence of cathepsin D in BALF correlates with reports of its expression by alveolar macrophages, bronchial epithelial cells and type I pneumocytes [124]. Cathepsin D increase in BALF of IPF patients is consistent with its potential role in remodelling processes occurring during fibrogenesis [91,124].

Our 2-DE studies not only allowed the confirmation of the status of disease markers for lung disorders diagnosis (SP-A, cathepsin D, for example), but also permitted the identification of new proteins in BALF. Human AOEB166 was for instance identified in BALF 2-DE gels (see Fig. 1) and microsequenced to enable reverse cloning of the complete gene. The protein, a peroxiredoxin widely expressed in human tissue, is thought to have a protective role in oxidation and inflammatory processes since LPS (lipopolysaccharide)-induced inflammation in rat lung is accompanied by an increase 



Fig. 1. Analytical silver-stained 2-DE gels of human BALF from a healthy subject (A) a patient with IPF (B) and a patient with sarcoidosis (C). $25 \mu \mathrm{g}$ proteins dissolved in $9 \mathrm{M}$ urea, $0.5 \% \mathrm{v} / \mathrm{v}$ Triton X-100, 2\% v/v Pharmalyte 3-10, $65 \mathrm{mM}$ DTE and $8 \mathrm{mM}$ PMSF were loaded on $\mathrm{pH} 3-10$ non-linear IPG strips for isoelectric focusing. Second dimensional separation of the proteins was done on ExcelGel XL 12-14\% and detected by silver staining. SP-A is absent in BALF of patients with IPF. Circles indicated small proteins up regulated in IPF (108: Cathepsin D, heavy chains; 172: FABP-E; 174: Cathepsin D, light chain; 179: Intestinal Trefoil Factor; 183: FABP-E; 194: Cathepsin D, light chain; 201, 202 and 206: Calgranulin A; 207: Saposin, D chain; 210: Ubiquitin-like protein; 212: Calcyclin; 216: Calvasculin) and the matching spots in healthy control. 
of lung AOEB166 mRNA levels [125]. Other unknown proteins detected in BALF, their tissue-specificity, their involvement in various lung disorders and their validations as lung disease markers are currently under investigation.

Finally, proteomic analysis of BAL fluid has also been recently described as enabling early, direct and sensitive monitoring of the actual impact of therapeutic interventions on specific BALF proteins, long before lung function parameters and structural changes are expected to be detected. BALF SP-A proteolysis levels were assessed, by immunoblotting of the SP-A degradation products displayed on 2-DE gels, to evaluate restoration, by alpha1-protease inhibitor treatment, of the protease-antiprotease imbalance in cystic fibrosis [126].

In conclusion, recent advances in proteomic analysis have enabled the identification of about $70 \%$ of BAL fluid protein spots displayed on 2-DE gels. These investigations confirm previous observations obtained by ELISA measurements and are consistent between different laboratories, which validate the use of 2-DE gels to compare BAL fluid protein levels between patients with lung disorders and healthy controls. The systematic sequencing of BAL fluid proteins is leading to the identification of numerous proteins of unknown function. Their possible use as new disease markers are currently being studied. Moreover, the everyday enrichment of the BALF 2-DE map by new protein sequences further facilitates comparisons betweens 2-DE gels, thereby accelerating the process of differentialdisplay proteomics involved in the identification of new disease markers. Finally, the 2-DE display of BAL fluid proteins permits the integrated analysis of numerous clinical parameters, which is often required to unambiguously and accurately establish a diagnosis of lung diseases and/or to check the influence of therapies on these clinical parameters.

\section{Future directions of BALF proteomics-based diagnosis of lung diseases}

Future research leading to efficient proteomics-based diagnosis of lung diseases has to be oriented in multiple directions. Completion of human BALF 2-DE protein map will require a significant increase in the number and intensity of displayed protein spots, for example through BAL fluid fractionation prior to 2-DE analysis, solubilization of hydrophobic proteins, increased staining sensitivity in conjunction with raised detec- tion limits for identification (e.g., by fluorescence staining), and use of smaller $\mathrm{pI}$ ranges which increase the first dimension resolution of proteins. High-throughput mass spectrometry-based methods, such as SELDITOF (Surface-Enhanced Laser Desorption/Ionisation Time Of Flight $[127,128]$ ), able to determine, in total protein extracts, unique protein profiles describing the progression from healthy to diseased states and back, will have to be implemented for BALF-based early diagnosis and therapy follow-up of lung diseases and for high-throughput identification of BALF components. Multiplying the molecular biological approaches to unravel the functional roles and the tissue specificity of the putative disease markers identified by proteomics will further increase confidence in the relevance of our observations and knowledge of the mechanisms involved in lung pathogenesis. On the other hand, the use of in vitro generated recombinant antibodies directed against all lung disease markers identified in BALF by proteomic analyses will give a very sensitive readout of the relative abundance of each marker in BALF or in other body fluids such as serum, induced sputum or breath condensates, monitored simultaneously by western blots, flow cytometry or antibody arrays.

\section{Acknowledgements}

Our work was supported by the Commission of the European Communities (QLK4-CT-1999-01308). R. Wattiez is a Research Associate at the National Funds for Scientific Research.

\section{References}

[1] R. Robbins and S. Rennard, Biology of airway epithelial cells, in: The Lung: Scientific Foundations, R. Crystal, J. West, E. Weibel and P. Barnes, eds, Lippincott-Raven, Philadelphia, 1996, PP. 445-457.

[2] Shak S. Mucins and lung secretions, in: The Lung: Scientific Foundations, R. Crystal, J. West, E. Weibel and P. Barnes, eds, Lippincott-Raven, Philadelphia, 1996, pp. 479-486.

[3] R. Lubman, K. Kim and E. Crandall, Alveolar epithelial barrier properties, in: The Lung: Scientific Foundations, R. Crystal, J. West, E. Weibel and P. Barnes, eds, LippincottRaven, Philadelphia, 1996, pp. 585-602.

[4] Hawgood, Surfactant: composition, structure, and metabolism, in: The Lung: Scientific Foundations, R. Crystal, J. West, E. Weibel and P. Barnes, eds, Lippincott-Raven, Philadelphia, 1996, PP. 557-571.

[5] F. Adams, T. Fujiwara, G. Emmanouilides and A. Scudder, Surface properties and lipids from lungs of infants with hyaline membrane disease, J Pediatr 66 (1965), 357-364. 
[6] B. Lachmann, P. Berggren, T. Curstedt, G. Grossmann and B. Robertson, Surfactant replacement in experimental respiratory distress syndrome induced by lung lavage, in: Current Concepts in Surfactant Research, P. von Wichert, ed., Karger, Basel München Paris, 1984, PP. 251-256.

[7] M. Griese, Pulmonary surfactant in health and human lung diseases: state of the art, Eur Respir J 13 (1999), 1455-1476.

[8] H.Y. Reynolds, Use of bronchoalveolar lavage in humans past necessity and future imperative, Lung 178 (2000), 271293.

[9] R.M. Rogers, M.S. Braunstein and J.F. Shurman, Role of bronchopulmonary lavage in the treatment of respiratory failure: a review, Chest 62 (1972), S95-106.

[10] F. Capron, Lavage Bronchoalvéolaire, Arch Anat Cytol Path 45 (1997), 255-260.

[11] F.E. Hargreave and R. Leigh, induced sputum, eosinophilic bronchitis, and chronic obstructive pulmonary disease, Am J Respir Crit Care Med 160 (1999), S53-57.

[12] N.R. Henig, M.R. Tonelli, M.V. Pier, J.L. Burns and M.L. Aitken, Sputum induction as a research tool for sampling the airways of subjects with cystic fibrosis, Thorax 56 (2001), 306-311.

[13] D. Olivieri, R. D'Ippolito and A. Chetta, induced sputum: diagnostic value in interstitial lung disease, Curr Opin Pulm Med 6 (2000), 411-414.

[14] L. Scheideler, H.G. Manke, U. Schwulera, O. inacker and H. Hammerle, Detection of nonvolatile macromolecules in breath. A possible diagnostic tool? Am Rev Respir Dis 148 (1993), 778-784.

[15] G. Becher, K. Winsel, E. Beck, G. Neubauer and E. Stresemann, Breath condensate as a method of noninvasive assessment of inflammation mediators from the lower airways, Pneumologie 51(2) (1997), 456-459.

[16] P. Reinhold, A. Langenberg, G. Becher and M. Rothe, Breath condensate - a medium obtained by a noninvasive method for the detection of inflammation mediators of the lung, Berl Munch Tierarztl Wochenschr 112 (1999), 254-259.

[17] A.H. Tiroke, B. Bewig and A. Haverich, Bronchoalveolar lavage in lung transplantation. State of the art, Clin Transplant 13 (1999), 131-157.

[18] G. Mikuz and A. Gschwendtner, Value of bronchoalvoeolar lavage in the diagnosis of lung disease, Verh Dtsch Ges Pathol 84 (2000), 129-135.

[19] J.A. Jacobs and E. De Brauwer, BAL fluid cytology in the assessment of infectious lung disease, Hosp Med 60 (1999), 550-555.

[20] Z. Chlap, U. Jedynak and K. Sladek, Mast cell: its significance in bronchoalveolar lavage fluid cytologic diagnosis of bronchial asthma and interstitial lung disease, Pneumonol Alergol Pol 66 (1998), 321-329.

[21] R.P. Daniele, J.A. Elias, P.E. Epstein and M.D. Rossman, Bronchoalveolar lavage: role in the pathogenesis, diagnosis, and management of interstitial lung disease, Ann intern Med 102 (1985), 93-108.

[22] H. Popper and M. Pongratz, Value and indications for bronchoalveolar lavage combined with transbronchial lung biopsy, Wien Klin Wochenschr 99 (1987), 848-855.

[23] D.G. James, G. Rizzato and O.P. Sharma, Bronchopulmonary lavage (BAL). A window of the lungs, Sarcoidosis 9 (1992), 3-14.

[24] M. Drent, M.A. van Nierop, F.A. Gerritsen, E.F. Wouters and P.G. Mulder, A computer program using BALF-analysis results as a diagnostic tool in interstitial lung diseases, Am J Respir Crit Care Med 153 (1996), 736-741.
[25] C.O. Beskow, C.B. Drachenberg and P.M. Bourquin et al., Diffuse alveolar damage. Morphologic features in bronchoalveolar lavage fluid, Acta Cytol 44 (2000), 640-646.

[26] N. Satake, S. Nagai and A. Kawatani et al., Density of phenotypic markers on BAL T-lymphocytes in hypersensitivity pneumonitis, pulmonary sarcoidosis and bronchiolitis obliterans with organizing pneumonia, Eur Respir J 6 (1993), 477-482.

[27] M. Raulf, V. Liebers, C. Steppert and X. Baur, increased gamma/delta-positive T-cells in blood and bronchoalveolar lavage of patients with sarcoidosis and hypersensitivity pneumonitis, Eur Respir J 7 (1994), 140-147.

[28] J. Wahlstrom, M. Berlin, C.M. Skold, H. Wigzell, A. Eklund and J. Grunewald, Phenotypic analysis of lymphocytes and monocytes/macrophages in peripheral blood and bronchoalveolar lavage fluid from patients with pulmonary sarcoidosis, Thorax 54 (1999), 339-346.

[29] E. Fireman, N. Vardinon and M. Burke et al., Predictive value of response to treatment of T-lymphocyte subpopulations in idiopathic pulmonary fibrosis, Eur Respir J 11 (1998), 706711.

[30] C. Albera, P. Ghio, P. Solidoro, I. Mabritto, L. Marchetti and E. Pozzi, Activated and memory alveolar T-lymphocytes in idiopathic eosinophilic pneumonia, Eur Respir J 8 (1995), 1281-1285.

[31] J. Kiemle-Kallee, H. Kreipe and H.J. Radzun et al., Alveolar macrophages in idiopathic pulmonary fibrosis display a more monocyte-like immunophenotype and an increased release of free oxygen radicals, Eur Respir J 4 (1991), 400-406.

[32] I. Striz, Y.M. Wang, I. Svarcova, L. Trnka, C. Sorg and U. Costabel, The phenotype of alveolar macrophages and its correlation with immune cells in bronchoalveolar lavage, Eur Respir J 6 (1993), 1287-1294.

[33] F. Moonens, C. Liesnard, F. Brancart, J.P. Van Vooren and E. Serruys, Rapid simple and nested polymerase chain reaction for the diagnosis of Pneumocystis carinii pneumonia, Scand J infect Dis 27 (1995), 358-362.

[34] G. Cathomas, M. Tamm, C.E. McGandy, A.P. Perruchoud, M.J. Mihatsch and P. Dalquen, Detection of herpesvirus-like DNA in the bronchoalveolar lavage fluid of patients with pulmonary Kaposi's sarcoma, Eur Respir J 9 (1996), 17431746.

[35] M. Fattal-German, F.L. Ladurie, J. Cerrina, F. Lecerf and S. Berrih-Aknin, Modulation of ICAM-1 expression in human alveolar macrophages in vitro, Eur Respir J 9 (1996), 463471.

[36] Y. Yu and G. Yang, Growth factor gene expression in bronchoalveolar lavage cells from patients with lung fibrosis, Chin Med Sci J 8 (1993), 172-176.

[37] R. Wattiez, C. Hermans, A. Bernard, O. Lesur and P. Falmagne, Human bronchoalveolar lavage fluid: twodimensional gel electrophoresis, amino acid microsequencing and identification of major proteins, Electrophoresis $\mathbf{2 0}$ (1999), 1634-1645.

[38] M. Lindahl, B. Stahlbom and C. Tagesson, Newly identified proteins in human nasal and bronchoalveolar lavage fluids: potential biomedical and clinical applications, Electrophoresis 20 (1999), 3670-3676.

[39] P. Ralph, I. Nakoinz and A. Sampson-Johannes et al., IL10, T lymphocyte inhibitor of human blood cell production of IL-1 and tumor necrosis factor, J Immunol 148 (1992), 808-814. 
[40] L. Armstrong and A.B. Millar, Relative production of tumour necrosis factor alpha and interleukin 10 in adult respiratory distress syndrome, Thorax 52 (1997), 442-446.

[41] T.L. Bonfield, M.W. Konstan, P. Burfeind, J.R. Panuska, J.B. Hilliard and M. Berger, Normal bronchial epithelial cells constitutively produce the anti-inflammatory cytokine interleukin-10, which is downregulated in cystic fibrosis, $A m$ J Respir Cell Mol Biol 13 (1995), 257-261.

[42] D.Y. Bell, J.A. Haseman, A. Spock, G. McLennan and G.E. Hook, Plasma proteins of the bronchoalveolar surface of the lungs of smokers and nonsmokers, Am Rev Respir Dis 124 (1981), 72-79.

[43] B. Muller and P. von Wichert, Bronchoalveolar lavage proteins, Klin Wochenschr 63 (1985), 781-787.

[44] R. White, A. Janoff and H.P. Godfrey, Secretion of Alpha2-macroglobulin by human alveolar macrophages, Lung 158 (1980), 9-14.

[45] J.E. Gadek, G.A. Fells, R.L. Zimmerman, S.I. Rennard and R.G. Crystal, Antielastases of the human alveolar structures. Implications for the protease-antiprotease theory of emphysema, J Clin invest 68 (1981), 889-898.

[46] M. Spatafora, A. Mirabella and G.A. Rossi et al., Lung inflammation in sarcoidosis: analysis of immunoglobulin levels in bronchoalveolar lavage fluid in active and inactive disease, Respiration 48 (1985), 127-135.

[47] O. Vandenplas, S. Depelchin, L. Delaunois, J.P. Delwiche and Y. Sibille, Bronchoalveolar lavage immunoglobulin A and $\mathrm{G}$ and antiproteases correlate with changes in diffusion indices during the natural course of pulmonary sarcoidosis, Eur Respir J 7 (1994), 1856-1864.

[48] F. Ratjen, W. Havers and J. Braun, intrapulmonary protein leakage in immunocompromised children and adults with pneumonia, Thorax 54 (1999), 432-436.

[49] J.F. Holter, J.E. Weiland, E.R. Pacht, J.E. Gadek and W.B. Davis, Protein permeability in the adult respiratory distress syndrome. Loss of size selectivity of the alveolar epithelium, J Clin invest 78 (1986), 1513-1522.

[50] C. Hermans and A. Bernard, Lung epithelium-specific proteins: characteristics and potential applications as markers, Am J Respir Crit Care Med 159 (1999), 646-678.

[51] P.G. Jorens, Y. Sibille and N.J. Goulding et al., Potential role of Clara cell protein, an endogenous phospholipase A2 inhibitor, in acute lung injury, Eur Respir J 8 (1995), 16471653.

[52] Y. Honda, H. Takahashi, N. Shijubo, Y. Kuroki and T. Akino, Surfactant protein-A concentration in bronchoalveolar lavage fluids of patients with pulmonary alveolar proteinosis, Chest 103 (1993), 496-499.

[53] Y. Honda, Y. Kuroki and E. Matsuura et al., Pulmonary surfactant protein D in sera and bronchoalveolar lavage fluids, Am J Respir Crit Care Med 152 (1995), 1860-1866.

[54] H.J. Kramer, R. Schmidt, A. Gunther, G. Becker, Y. Suzuki and W. Seeger, ELISA technique for quantification of surfactant protein B (SP-B) in bronchoalveolar lavage fluid, Am J Respir Crit Care Med 152 (1995), 1540-1544.

[55] N. Shijubo, Y. Itoh and T. Yamaguchi et al., Serum and BAL Clara cell $10 \mathrm{kDa}$ protein (CC10) levels and CC10-positive bronchiolar cells are decreased in smokers, Eur Respir $J \mathbf{1 0}$ (1997), 1108-1114.

[56] T. Takahashi, M. Munakata, I. Suzuki and Y. Kawakami, Serum and bronchoalveolar fluid KL-6 levels in patients with pulmonary alveolar proteinosis, Am J Respir Crit Care Med 158 (1998), 1294-1298.
[57] N. Shijubo, Y. Itoh, T. Yamaguchi and S. Abe, Development of an enzyme-linked immunosorbent assay for Clara cell 10$\mathrm{kDa}$ protein: in pursuit of clinical significance of sera in patients with asthma and sarcoidosis, Ann N Y Acad Sci $\mathbf{9 2 3}$ (2000), 268-279.

[58] H. Hamm, J. Luhrs, Y. Guzman, J. Rotaeche, U. Costabel, H. Fabel and W. Bartsch, Elevated surfactant protein A in bronchoalveolar lavage fluids from sarcoidosis and hypersensitivity pneumonitis patients, Chest 106 (1994), 1766-1770.

[59] Y. Kuroki, H. Takahashi, H. Chiba and T. Akino, Surfactant proteins A and D: disease markers, Biochim Biophys Acta 1408 (1998), 334-345.

[60] N. Kohno, Y. Awaya and T. Oyama et al., KL-6, a mucin-like glycoprotein, in bronchoalveolar lavage fluid from patients with interstitial lung disease, Am Rev Respir Dis 148 (1993), 637-642.

[61] C. Hermans and A. Bernard, Pneumoproteinaemia: a new perspective in the assessment of lung disorders, Eur Respir J 11 (1998), 801-803.

[62] S.C. Donnelly, R.M. Strieter and P.T. Reid et al., The association between mortality rates and decreased concentrations of interleukin-10 and interleukin-1 receptor antagonist in the lung fluids of patients with the adult respiratory distress syndrome, Ann intern Med 125 (1996), 191-196.

[63] G.U. Meduri, S. Headley and G. Kohler et al., Persistent elevation of inflammatory cytokines predicts a poor outcome in ARDS. Plasma IL-1 beta and IL-6 levels are consistent and efficient predictors of outcome over time, Chest 107 (1995), 1062-1073.

[64] L. Armstrong, N.M. Foley and A.B. Millar, inter-relationship between tumour necrosis factor-alpha (TNF-alpha) and TNF soluble receptors in pulmonary sarcoidosis, Thorax $\mathbf{5 4}$ (1999), 524-530.

[65] J. Ashitani, H. Mukae and H. Taniguchi et al., Granulocytecolony stimulating factor levels in bronchoalveolar lavage fluid from patients with idiopathic pulmonary fibrosis, Tho$\operatorname{rax} 54$ (1999), 1015-1020.

[66] H. Abul, A. Abul, I. Khan, T.C. Mathew, A. Ayed and E. AlAthary, Levels of IL-8 and myeloperoxidase in the lungs of pneumonia patients, Mol Cell Biochem 217 (2001), 107-112.

[67] T.C. Tsao, J. Hong, C. Huang, P. Yang, S.K. Liao and K.S. Chang, increased TNF-alpha, IL-1 beta and IL-6 levels in the bronchoalveolar lavage fluid with the upregulation of their mRNA in macrophages lavaged from patients with active pulmonary tuberculosis, Tuber Lung Dis 79 (1999), 279-285.

[68] K.J. Rozyk, T. Plusa, P. Kuna and E. Pirozynska, Monocyte chemotactic and activating factor/monocyte chemoattractant protein in bronchoalveolar lavage fluid from patients with atopic asthma and chronic bronchitis. Relationship to lung function tests, bronchial hyper-responsiveness and cytology of bronchoalveolar lavage fluid, Immunol Lett 58 (1997), 47-52.

[69] B. Lamkhioued, E.A. Garcia-Zepeda and S. Abi-Younes et al., Monocyte chemoattractant protein (MCP)-4 expression in the airways of patients with asthma. induction in epithelial cells and mononuclear cells by proinflammatory cytokines, Am J Respir Crit Care Med 162 (2000), 723-732.

[70] B. Lamkhioued, P.M. Renzi and S. Abi-Younes et al., increased expression of eotaxin in bronchoalveolar lavage and airways of asthmatics contributes to the chemotaxis of eosinophils to the site of inflammation, J Immunol 159 (1997), 4593-4601.

[71] G.A. Finlay, K.J. Russell and K.J. McMahon et al., Elevated levels of matrix metalloproteinases in bronchoalveolar lavage 
fluid of emphysematous patients, Thorax 52 (1997), 502506.

[72] S.E. Wenzel, AA. Fowler 3rd and L.B. Schwartz, Activation of pulmonary mast cells by bronchoalveolar allergen challenge. in vivo release of histamine and tryptase in atopic subjects with and without asthma, Am Rev Respir Dis $\mathbf{1 3 7}$ (1988), 1002-1008.

[73] E. Lakari, P. Paakko and V.L. Kinnula, Manganese superoxide dismutase, but not $\mathrm{CuZn}$ superoxide dismutase, is highly expressed in the granulomas of pulmonary sarcoidosis and extrinsic allergic alveolitis, Am J Respir Crit Care Med 158 (1998), 589-596.

[74] K. Maier, L. Leuschel and U. Costabel, increased levels of oxidized methionine residues in bronchoalveolar lavage fluid proteins from patients with idiopathic pulmonary fibrosis, Am Rev Respir Dis 143 (1991), 271-274.

[75] K.L. Maier, L. Leuschel and U. Costabel, increased oxidized methionine residues in BAL fluid proteins in acute or chronic bronchitis, Eur Respir J 5 (1992), 651-658.

[76] A.G. Lenz, U. Costabel and K.L. Maier, Oxidized BAL fluid proteins in patients with interstitial lung diseases, Eur Respir J9 (1996), 307-312.

[77] A.G. Lenz, P.G. Jorens and B. Meyer et al., Oxidatively modified proteins in bronchoalveolar lavage fluid of patients with ARDS and patients at-risk for ARDS, Eur Respir J 13 (1999), 169-174.

[78] J. Schildge, B. Klar and N. Weinstock, Concentration of alkaline phosphatase (AP) and AP/albumin ratio in bronchoalveolar lavage (BAL) for the diagnosis of interstitial lung diseases, Pneumologie 54 (2000), 385-391.

[79] G. Matute-Bello, W.C. Liles and K.P. Steinberg et al., Soluble Fas ligand induces epithelial cell apoptosis in humans with acute lung injury (ARDS), J Immunol 163 (1999), 22172225 .

[80] K. Kuwano, M. Kawasaki and T. Maeyama et al., Soluble form of fas and fas ligand in BAL fluid from patients with pulmonary fibrosis and bronchiolitis obliterans organizing pneumonia, Chest 118 (2000), 451-458.

[81] J. Domagala-Kulawik, P. Droszcz, I. Kraszewska and R. Chazan, Expression of Fas antigen in the cells from bronchoalveolar lavage fluid (BALF), Folia Histochem Cytobiol 38 (2000), 185-188.

[82] A.E. Calogero, R. Polosa, E. Neville and R. D'Agata, Measurements of hormonal peptides in the bronchoalveolar fluid as tumor markers of lung cancer, $J$ Endocrinol invest 18 (1995), 354-358.

[83] V. Macchia, A. Mariano and M. Cavalcanti et al., Tumor markers and lung cancer: correlation between serum and bronchial secretion levels of CEA, TPA, CanAg CA-50, NSE and ferritin, Int J Biol Markers 2 (1987), 151-156.

[84] J. Niklinski, E. Chyczewska, M. Furman, E. Kowal, J. Laudanski and L. Chyczewski, Usefulness of a multiple biomarker assay in bronchoalveolar lavage (BAL) and serum for the diagnosis of small cell lung cancer, Neoplasma $\mathbf{4 0}$ (1993), 305-308.

[85] T.C. Pina, I.T. Zapata, F.C. Hernandez, J.B. Lopez, P.P. Paricio and P.M. Hernandez, Tumour markers in serum, bronchoalveolar lavage and biopsy cytosol in lung carcinoma: what environment lends the optimum diagnostic yield? Clin Chim Acta 305 (2001), 27-34.

[86] X.Y. Li, I. Rahman, K. Donaldson and W. MacNee, Mechanisms of cigarette smoke induced increased airspace permeability, Thorax 51 (1996), 465-471.
[87] R.E. Nocker, J.S. van der Zee, F.R. Weller, F.J. van Overveld, H.M. Jansen and T.A. Out, Segmental allergen challenge induces plasma protein leakage into the airways of asthmatic subjects at 4 hours but not at 5 minutes after challenge, $J \mathrm{Lab}$ Clin Med 134 (1999), 74-82.

[88] A.S. Titanian, R.P. Selitskaia and A.C. Kim, Determination of the concentration of immunoglobulins and other proteins in bronchoalveolar fluid of patients with various types of pulmonary pathology, Ter Arkh 59 (1987), 48-51.

[89] M. Lindahl, B. Stahlbom, J. Svartz and C. Tagesson, Protein patterns of human nasal and bronchoalveolar lavage fluids analyzed with two-dimensional gel electrophoresis, Electrophoresis 19 (1998), 3222-3229.

[90] A.G. Lenz, B. Meyer, U. Costabel and K. Maier, Bronchoalveolar lavage fluid proteins in human lung disease: analysis by two-dimensional electrophoresis, Electrophoresis 14 (1993), 242-244.

[91] R. Wattiez, C. Hermans, C. Cruyt, A. Bernard and P. Falmagne, Human bronchoalveolar lavage fluid protein twodimensional database: study of interstitial lung diseases, Electrophoresis 21 (2000), 2703-2712.

[92] T. Plusa and Z. Wasek, Immunobiochemical evaluation of bronchoalveolar lavage (BAL) in atopic bronchial asthma, chronic bronchitis and bronchiectasis, Allergol Immunopathol (Madr) 15 (1987), 209-213.

[93] K. Shigehara, N. Shijubo and M. Ohmichi et al., increased levels of interleukin-18 in patients with pulmonary sarcoidosis, Am J Respir Crit Care Med 162 (2000), 1979-1982.

[94] M. Laan, I. Qvarfordt, G.C. Riise, B.A. Andersson, S. Larsson and A. Linden, increased levels of interleukin-16 in the airways of tobacco smokers: relationship with peripheral blood T lymphocytes, Thorax 54 (1999), 911-916.

[95] D.S. Kim, Y.G. Jeon and T.S. Shim et al., The value of interleukin-12 as an activity marker of pulmonary sarcoidosis, Sarcoidosis Vasc Diffuse Lung Dis 17 (2000), 271-276.

[96] L. Borish, A. Aarons, J. Rumbyrt, P. Cvietusa, J. Negri and $\mathrm{S}$. Wenzel, interleukin-10 regulation in normal subjects and patients with asthma, J Allergy Clin Immunol 97 (1996), 1288-1296.

[97] T.L. Bonfield, J.R. Panuska and M.W. Konstan et al., inflammatory cytokines in cystic fibrosis lungs, Am J Respir Crit Care Med 152 (1995), 2111-2118.

[98] M.G. Kiehl, H. Ostermann, M. Thomas, T. Birkfellner and J. Kienast, inflammatory mediators in BAL fluid as markers of evolving pneumonia in leukocytopenic patients, Chest 112 (1997), 1214-1220.

[99] A. Itoh, E. Yamaguchi, K. Furuya and Y. Kawakami, Secretion of GM-CSF by inflammatory cells in the lung of patients with sarcoidosis, Respirology 3 (1998), 247-251.

[100] M.S. Carraway, A.J. Ghio, J.D. Carter and C.A. Piantadosi, Detection of granulocyte-macrophage colony-stimulating factor in patients with pulmonary alveolar proteinosis, Am J Respir Crit Care Med 161 (2000), 1294-1299.

[101] K. Jahnz-Rozyk, A. Chcialowski, E. Pirozynska and A. Rogalewska, Expression of adhesion molecules LFA-1 (CD11a and ICAM-1 (CD54) on lymphocytes and chemokines IL-8 and MCP-1 concentrations in bronchoalveolar lavage of patients with asthma or chronic obstructive pulmonary disease, Pol Merkuriusz Lek 9 (2000), 649-652.

[102] B.D. Car, F. Meloni, M. Luisetti, G. Semenzato, G. GialdroniGrassi and A. Walz, Elevated IL-8 and MCP-1 in the bronchoalveolar lavage fluid of patients with idiopathic pulmonary fibrosis and pulmonary sarcoidosis, Am J Respir Crit Care Med 149 (1994), 655-659. 
[103] Y. Sugiyama, T. Kasahara, N. Mukaida, K. Matsushima and S. Kitamura, Chemokines in the bronchoalveolar lavage fluid of patients with sarcoidosis, Intern Med 36 (1997), 856-860.

[104] M. Ennis, G. Turner and B.C. Schock et al., inflammatory mediators in bronchoalveolar lavage samples from children with and without asthma, Clin Exp Allergy 29 (1999), 362366.

[105] R. Kalenderian, L. Raju, W. Roth, L.B. Schwartz, B. Gruber and A. Janoff, Elevated histamine and tryptase levels in smokers' bronchoalveolar lavage fluid. Do lung mast cells contribute to smokers' emphysema? Chest 94 (1988), 119123.

[106] S.M. Stahl, New drug discovery in the postgenomic era: from genomics to proteomics, J Clin Psychiatry 61 (2000), 894-895.

[107] G. Lubec, M. Nonaka, K. Krapfenbauer, M. Gratzer, N. Cairns and M. Fountoulakis, Expression of the dihydropyrimidinase related protein 2 (DRP-2) in Down syndrome and Alzheimer's disease brain is downregulated at the mRNA and dysregulated at the protein level, J Neural Transm Suppl 57 (1999), 161-177.

[108] A.A. Alaiya, B. Franzen, G. Auer and S. Linder, Cancer proteomics: from identification of novel markers to creation of artifical learning models for tumor classification, Electrophoresis 21 (2000), 1210-1217.

[109] P.R. Jungblut, U. Zimny-Arndt and E. Zeindl-Eberhart et al., Proteomics in human disease: cancer, heart and infectious diseases, Electrophoresis 20 (1999), 2100-2110.

[110] C.P. McAtee, K.E. Fry and D.E. Berg, Identification of potential diagnostic and vaccine candidates of Helicobacter pylori by \&quot;proteome\&quot; technologies, Helicobacter 3 (1998), 163-169.

[111] P.R. Jungblut, D. Bumann and G. Haas et al., Comparative proteome analysis of Helicobacter pylori, Mol Microbiol 36 (2000), 710-725.

[112] S. Kennedy, Proteomic profiling from human samples: the body fluid alternative, Toxicol Lett 120 (2001), 379-384

[113] A. Pandey and M. Mann, Proteomics to study genes and genomes, Nature 405 (2000), 837-846.

[114] D.Y. Bell and G.E. Hook, Pulmonary alveolar proteinosis: analysis of airway and alveolar proteins, Am Rev Respir Dis 119 (1979), 979-990.

[115] R. Westermeier, W. Postel, J. Weser and A. Gorg, Highresolution two-dimensional electrophoresis with isoelectric focusing in immobilized $\mathrm{pH}$ gradients, $J$ Biochem Biophys Methods 8 (1983), 321-330.

[116] A.G. Lenz, B. Meyer, H. Weber and K. Maier, Twodimensional electrophoresis of dog bronchoalveolar lavage fluid proteins, Electrophoresis 11 (1990), 510-513.

[117] F.X. McCormack, T.E. Jr. King, D.R. Voelker, P.C. Robinson and R.J. Mason, Idiopathic pulmonary fibrosis. Abnormalities in the bronchoalveolar lavage content of surfactant protein A, Am Rev Respir Dis 144 (1991), 160-166.

[118] M. Lindahl, B. Stahlbom and C. Tagesson, Two-dimensional gel electrophoresis of nasal and bronchoalveolar lavage fluids after occupational exposure, Electrophoresis 16 (1995), 1199-1204.

[119] M. Lindahl, J. Svartz and C. Tagesson, Demonstration of different forms of the anti-inflammatory proteins lipocortin-1 and Clara cell protein-16 in human nasal and bronchoalveolar lavage fluids, Electrophoresis 20 (1999), 881-890.

[120] M. Lindahl, T. Ekstrom, J. Sorensen and C. Tagesson, Two dimensional protein patterns of bronchoalveolar lavage fluid from non-smokers, smokers, and subjects exposed to asbestos, Thorax 51 (1996), 1028-1035.

[121] B. Redl, P. Wojnar, H. Ellemunter and H. Feichtinger, Identification of a lipocalin in mucosal glands of the human tracheobronchial tree and its enhanced secretion in cystic fibrosis, Lab Invest 78 (1998), 1121-1129.

[122] W. van't Hof, M.F. Blankenvoorde, E.C. Veerman and A.V. Amerongen, The salivary lipocalin von Ebner's gland protein is a cysteine proteinase inhibitor, J Biol Chem 272 (1997), 1837-1841.

[123] F. Ogushi, S. Sone and K. Tani et al., Identification and localization of immunoglobulin binding factor in bronchoalveolar lavage fluid from healthy smokers, Am J Respir Crit Care Med 152 (1995), 2133-2137.

[124] M. Kasper, P. Lackie, M. Haase, D. Schuh and M. Muller, Immunolocalization of cathepsin D in pneumocytes of normal human lung and in pulmonary fibrosis, Virchows Arch 428 (1996), 207-215.

[125] B. Knoops, A. Clippe and C. Bogard et al., Cloning and characterization of AOEB166, a novel mammalian antioxidant enzyme of the peroxiredoxin family, J Biol Chem 274 (1999), 30451-30458.

[126] M. Griese, C. von Bredow and P. Birrer, Reduced proteolysis of surfactant protein A and changes of the bronchoalveolar lavage fluid proteome by inhaled alpha 1-protease inhibitor in cystic fibrosis, Electrophoresis 22 (2001), 165-171.

[127] M. Merchant and S.R. Weinberger, Recent advancements in surface-enhanced laser desorption/ionization-time of flightmass spectrometry, Electrophoresis 21 (2000), 1164-1177.

[128] R.B. Rubin and M. Merchant, A rapid protein profiling system that speeds study of cancer and other diseases, Am Clin Lab 19 (2000), 28-29. 


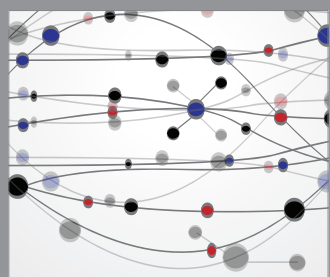

The Scientific World Journal
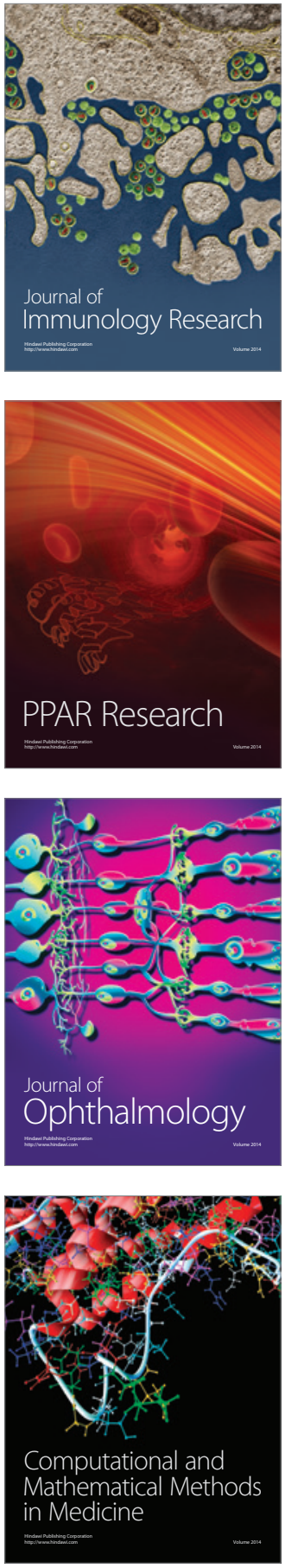

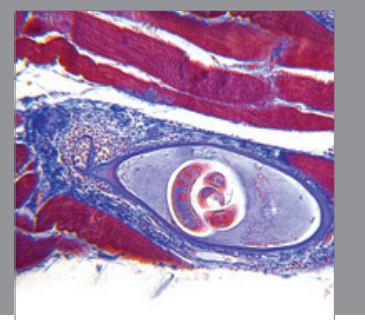

Gastroenterology

Research and Practice
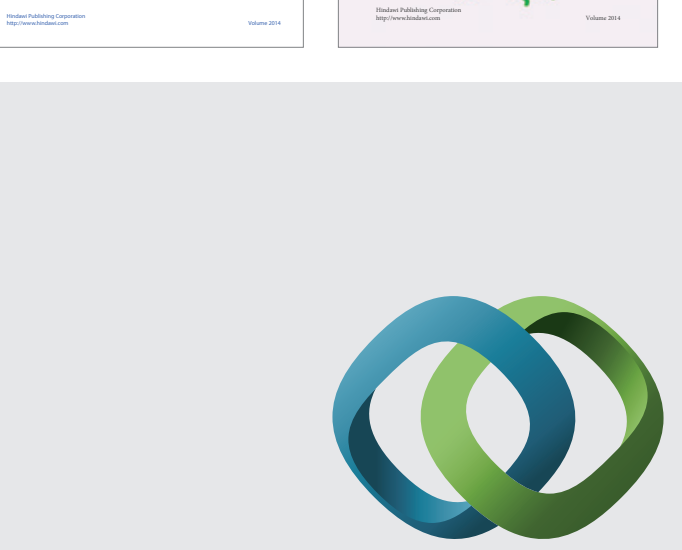

\section{Hindawi}

Submit your manuscripts at

http://www.hindawi.com
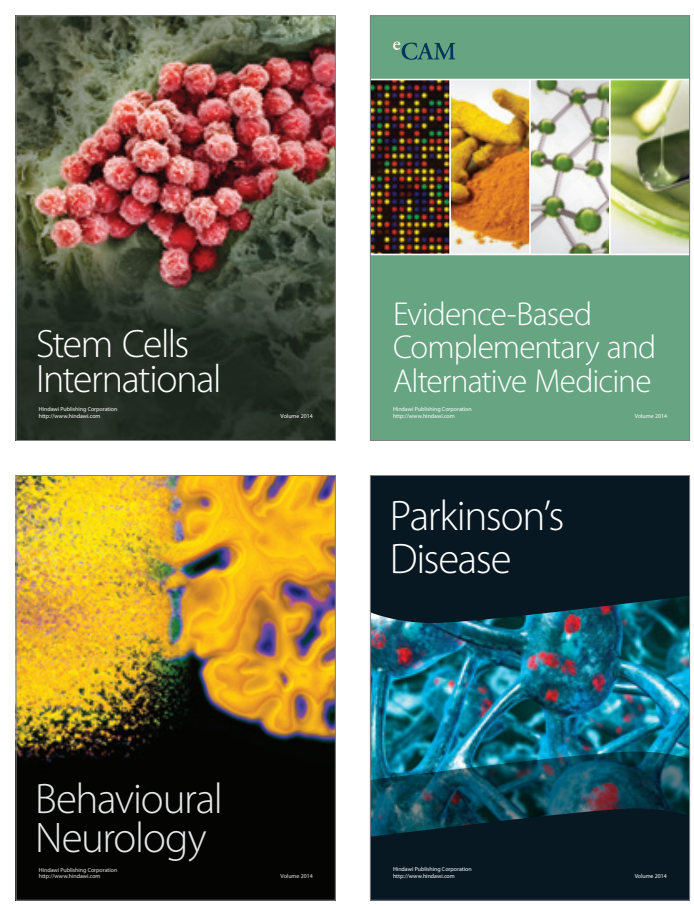

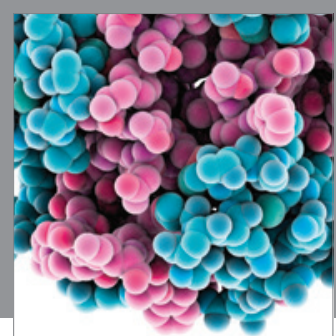

Journal of
Diabetes Research

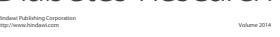

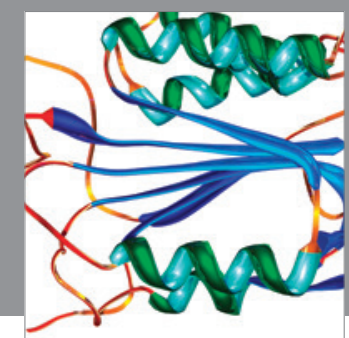

Disease Markers
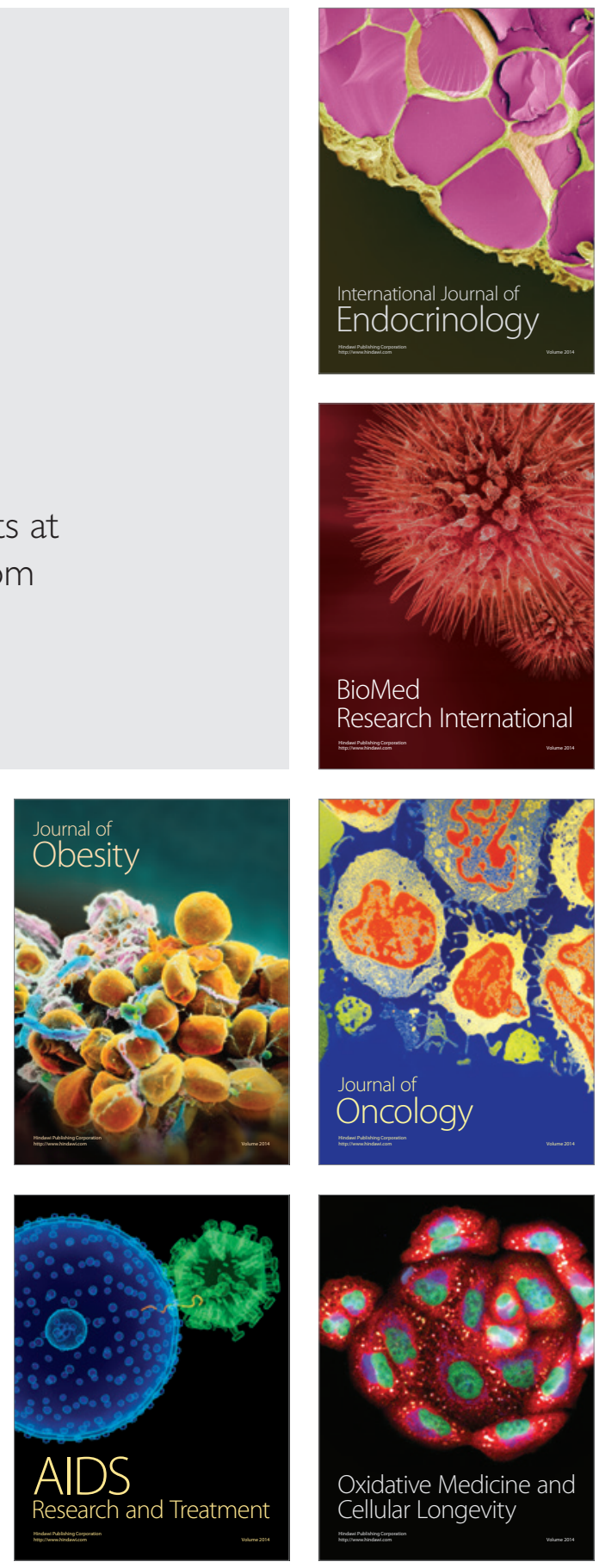